\title{
Critical fermentation factors that influence the production of multiple bacteriocins of Enterococcus faecium NKR-5-3
}

\author{
Rodney H. Perez ${ }^{1 * 2}$, Kohei Himeno ${ }^{2}$, Takeshi Zendo ${ }^{2}$ and Kenji Sonomoto ${ }^{2}$
}

\begin{abstract}
Submitted: 17 February 2020 | Accepted: 09 June 2020

Bacteriocins from lactic acid bacteria (LAB) are industrially important compounds that have been utilized as a safe food preservative replacing the potentially harmful synthetic chemical preservatives. Enterococcus faecium NKR-5-3 is a novel LAB strain that produces five different bacteriocins. The critical fermentation factors, such as specific medium components and optimum incubation temperature that support the maximum production of multiple bacteriocins of strain NKR-5-3, were identified. Sucrose and yeast extract were found to be the preferred carbon and nitrogen sources for bacteriocin production of this strain, respectively. The highest bacteriocin production was observed when strain NKR-5-3 was incubated at $25^{\circ} \mathrm{C}$. At incubation temperatures beyond $30^{\circ} \mathrm{C}$, bacteriocin production was significantly reduced and completely ceased when further raised to $40^{\circ} \mathrm{C}$. These findings possess remarkable practical implications as they can be vital in the future design of a cost-effective production system for these bacteriocins. Such a system would address the issue of the high production cost, which has remained the major barrier to the development of the large-scale industrial utilization of these important compounds.
\end{abstract}

Keywords: lactic acid bacteria, Enterococcus faecium, bacteriocin, multiple bacteriocin, bacteriocin production, fermentation factors

'National Institute of Molecular Biology and Biotechnology (BIOTECH), University of the Philippines Los Baños (UPLB), Los Baños, Laguna, Philippines

2Department of Bioscience and Biotechnology, Faculty of Agriculture, Graduate School, Kyushu

University, Japan

*Corresponding Author. Address: National Institute of Molecular Biology and Biotechnology (BIOTECH), University of the Philippines Los Baños (UPLB), Los Baños, Laguna, Philippines; Email: rhperez@up.edu.ph DOI: $10.32945 /$ atr4226.2020 


\section{Critical fermentation factors that influence the production of multiple bacteriocins}

\section{INTRODUCTION}

Lactic acid bacteria (LAB) are a family of microorganisms that are indispensable for the food industry. They have a long history of many applications in food fermentation that dates back to ancient times. It is a well-established fact that LAB have a beneficial influence on the shelf-life of fermented foods as well as their nutritional and organoleptic properties (De Vuyst \& Leroy 2007). One of the many attractive attributes of $L A B$ is their ability to produce antimicrobial compounds such as bacteriocins. Bacteriocins are a diverse family of ribosomally synthesized bioactive peptides that have potent antimicrobial activity against many industrially relevant bacterial strains, including many food spoilage and food-borne pathogenic strains (Cleveland et al 2001, Chen \& Hoover 2003). The Food and Drug Administration of the United States (USFDA) classified LAB and their by-products as Generally Regarded as Safe (GRAS) as human food ingredients. Bacteriocins from $L A B$ have been utilized as safe food preservatives to replace potentially harmful synthetic chemical preservatives. Bacteriocins from LAB possess a number of desirable properties that make them particularly attractive for application in the food industry. These compounds possess inherent tolerance to high thermal conditions as well as stable bioactivity over a wide $\mathrm{pH}$ range common in many food systems. Moreover, the absence of any distinct organoleptic properties, which could interfere with the overall food sensory quality, further enhances the utility of bacteriocins as food preservatives (Perez et al 2014). However, their utilization in the food industry has remained limited despite the highly desirable properties of bacteriocins. Up to now, nisin A, and to a lesser extent, pediocin PA-1, have remained the only commercially available bacteriocins despite a vast array of new bacteriocins being discovered (Cotter et al 2005). One of the major reasons for the underutilization of bacteriocin is its significantly high production cost. Identifying the critical fermentation factors that influence bacteriocin production is therefore important in the design of viable, costeffective strategies that can significantly reduce production costs.

Meanwhile, Enterococcus faecium NKR-5-3 is a novel LAB strain that is capable of producing multiple bacteriocins. This strain synthesizes five different bacteriocin peptides, enterocins NKR-5-3A, Z, B, C and D (Ent53A, Z, B, C \& D), which belong to different class II sub-classes (Ishibashi et al 2012). Ent53A and $Z$ belong to the family of two-peptide bacteriocins or class Ilb bacteriocins known for the synergistic activity of the peptide components. Ent53B is a circular bacteriocin (class IIc), a group of bacteriocins known for their exceptional stability emanating from their unique circular backbone structure (Himeno et al 2015). Ent53C is a class Ila bacteriocin which are the pediocin-like bacteriocins known for their exceptionally potent bioactivity against Listeria monocytogenes - a highly pathogenic food-borne bacteria (Himeno et al 2012). Whereas, Ent53D belongs to the heterogeneous class IId bacteriocin. This exhibits a pheromone-like activity that can induce the biosynthesis of the other NKR-5-3 bacteriocins (Ishibashi et al 2012).

The biosynthetic machinery responsible for the production of the multiple bacteriocins of strain NKR-5-3 is already well characterized (Ishibashi et al 2014, Perez et al 2016). One major component of its multiple bacteriocin biosynthetic machinery is the unique production regulatory mechanism wherein the production of four (Ent53A, Z, C \& D) of the five bacteriocins is controlled by a single system 
enabling the producer strain to efficiently conserve its energy (Ishibashi et al In press). This unique production regulatory mechanism involves a tight interplay of a histidine kinase protein, a response regulator, and an inducing molecule that is responsible for the coordinated expression of the bacteriocin biosynthetic genes. This regulation mechanism is known as a quorum-sensing system wherein an inducing molecule activates the series of phosphorylation reactions of the histidine kinase and response regulator proteins resulting in the activation of the transcription of the biosynthetic genes related to the production of Ent53A, Z, C and $D$ (Ishibashi et al In press). Whereas the biosynthesis of the circular bacteriocin, Ent53B, is independent of this quorum-sensing regulatory system (Perez et al 2016).

Although it is understood that the molecular mechanism of bacteriocin biosynthesis is controlled at the gene transcription level through the quorumsensing system, fermentation conditions such as the ionic strength, $\mathrm{pH}$, components of the cultivation media as well as incubation temperature have also been demonstrated to have an indirect effect on this regulatory system. Hence, in this present study, the influence of some fermentation factors on the production of the multiple bacteriocins of strain NKR-5-3 were identified. The correlation between specific medium components and incubation temperature and cell growth and bacteriocin production was established. The identification of the critical fermentation factors for bacteriocin production will be useful in the future establishment of a cost-effective production system of the multiple bacteriocins of strain NKR-5-3.

\section{MATERIALS AND METHODS}

\section{Bacterial Strains and Culture Conditions}

The multiple bacteriocin-producing strain E. faecium NKR-5-3 was cultivated in the M17 medium (Merck, Darmstadt, Germany), MRS medium (Oxoid, Hampshire, UK), or in a modified M17 medium as specified, and incubated at $30^{\circ} \mathrm{C}$ for $24 \mathrm{~h}$. The indicator strains Lactobacillus sakei subsp. sakei JCM $1157^{\top}$, E. faecalis JCM 5803, Bacillus subtilis JCM 1465 were cultivated in MRS medium, and Tryptic Soy Broth (Difco, Sparks, OK, USA) supplemented with $0.6 \%$ Yeast Extract (Nacalai Tesque, Kyoto, Japan) (TSBYE), respectively and incubated at $30^{\circ} \mathrm{C}$ for $24 \mathrm{~h}$. All bacteria were stored at $-80^{\circ} \mathrm{C}$ in their respective media with $30 \%(\mathrm{w} / \mathrm{v})$ glycerol and cultivated twice before use.

\section{Bacteriocin Activity Assay}

Estimation of bacteriocin production was determined using the spot-on-lawn method as described by Ishibashi et al 2012. Briefly, 10L of two-fold dilutions of culture supernatant were spotted onto a double-layered agar plate comprising $5 \mathrm{~mL}$ of lactobacilli agar AOAC (Difco, Sparks, MD, USA) inoculated with an overnight culture of an indicator strain as an upper layer and $10 \mathrm{~mL}$ of MRS medium supplemented with $1.2 \%$ agar (Nacalai Tesque, Kyoto, Japan) as a bottom layer. Two indicator strains E. faecalis JCM 5803 and Bacillus subtilis JCM 1465 were used to monitor the cluster bacteriocin production. The latter indicator strain was 


\section{Critical fermentation factors that influence the production of multiple bacteriocins}

sensitive only to Ent53B bacteriocin, whereas the former is sensitive to all NKR-5-3 enterocins (Ishibashi et al 2012). In the case when the overall bacteriocin production was monitored, $L$. sakie subs. sakie JCM 1157 was used as the indicator strain. This strain was most sensitive to all NKR-5-3 bacteriocins and hence was able to detect small changes in bacteriocin production. After overnight incubation at appropriate temperatures for indicator strains, bacterial lawns were checked for inhibition zones. Estimated bacteriocin activity was defined as the reciprocal of the highest dilution, causing a clear zone of growth inhibition in the indicator lawn expressed in activity units $(A U)$ per volume of culture supernatant.

\section{Influence of Culture Media, Carbon and Nitrogen Source on Bacteriocin Production}

In order to test the appropriate cultivation media for bacteriocin production of strain NKR-5-3, the three common media for the cultivation of LAB, M17, MRS, and TSBYE were tested. Strain NKR-5-3 was individually propagated in these media, and subsequent bacteriocin production and growth were monitored.

The preferred nitrogen and carbon source of strain NKR-5-3 were determined by preparing a modified M17 medium containing a single nitrogen or carbon source. All modified media were prepared according to the standard composition of the M17 medium, as summarized in Table 1. The modified M17 media were then used for the cultivation of strain NKR-5-3. All cultivations were performed in $200 \mathrm{~mL}$ of media in $500 \mathrm{~mL}$ Erlenmeyer flasks without shaking at $30^{\circ} \mathrm{C}$. Samples were then taken after $24 \mathrm{~h}$ and assayed for bacteriocin production, as described above. Cell growth was monitored by quantifying the optical density measured at $600 \mathrm{~nm}$, whereas $\mathrm{pH}$ was monitored using a standard $\mathrm{pH}$ meter.

Table 1. Standard composition of M17 medium

\begin{tabular}{lc}
\multicolumn{1}{c}{ Component } & Amount (g per L) \\
\hline Nitrogen source & 5.00 \\
polypeptone & 5.00 \\
phytone & 2.50 \\
yeast extract & 5.00 \\
beef extract & 5.00 \\
Carbon source & \\
lactose & 5.00 \\
Mineral salts and vitamins & \\
ascorbic acid & 0.50 \\
di-sodium- $\beta$-glycerolphosphate & 19.00 \\
$\mathrm{MgSO}_{4}$ & 0.25 \\
\hline
\end{tabular}

\section{Supplementation of critical carbon and nitrogen source}

Two levels $(0.5 \& 1.0 \%)$ of the identified critical carbon and nitrogen source was supplemented into both M17 and TSB media and used in the propagation of strain NKR-5-3. Growth, bacteriocin production, and specific bacteriocin productivity were monitored as described above. 


\section{Influence of Incubation Temperature}

The influence of the incubation temperature on multiple bacteriocin production of strain NKR-5-3 was determined by cultivating it at different incubation temperatures ranging from 20 to $40^{\circ} \mathrm{C}$ in standard M17 medium. After 24h incubation, growth and bacteriocin production were monitored.

\section{RESULTS}

\section{Influence of Standard Cultivation Media on Bacteriocin Production}

The three common LAB cultivation media M17, MRS, and TSBYE were evaluated for their influence on the production of multiple bacteriocins of E. faecium NKR-5-3. Significant variability of the total bacteriocin activity was observed against the indicator strain E. faecalis JCM 5803 (sensitive to all NKR-5-3 bacteriocins) for all three media. Surprisingly, against the B. subtilis JCM 1465, an indicator strain sensitive only to Ent53B, comparable bioactivity was detected in M17 and MRS media. The highest bioactivity was detected in M17, whereas TSBYE had the lowest bacteriocin activity. Despite considerably comparable growth in MRS and M17 media, bacteriocin activity against $E$. faecalis JCM 5803 had a 3.8-fold difference in specific bacteriocin production, a measure of bacteriocin production per bacterial cell. When strain NKR-5-3 was cultivated in the TSBYE medium, no bacteriocin activity was detected against $E$. faecalis JCM 5803. However, considerable bacteriocin activity was detected against $B$. subtilis JCM 1465 in TSBYE.

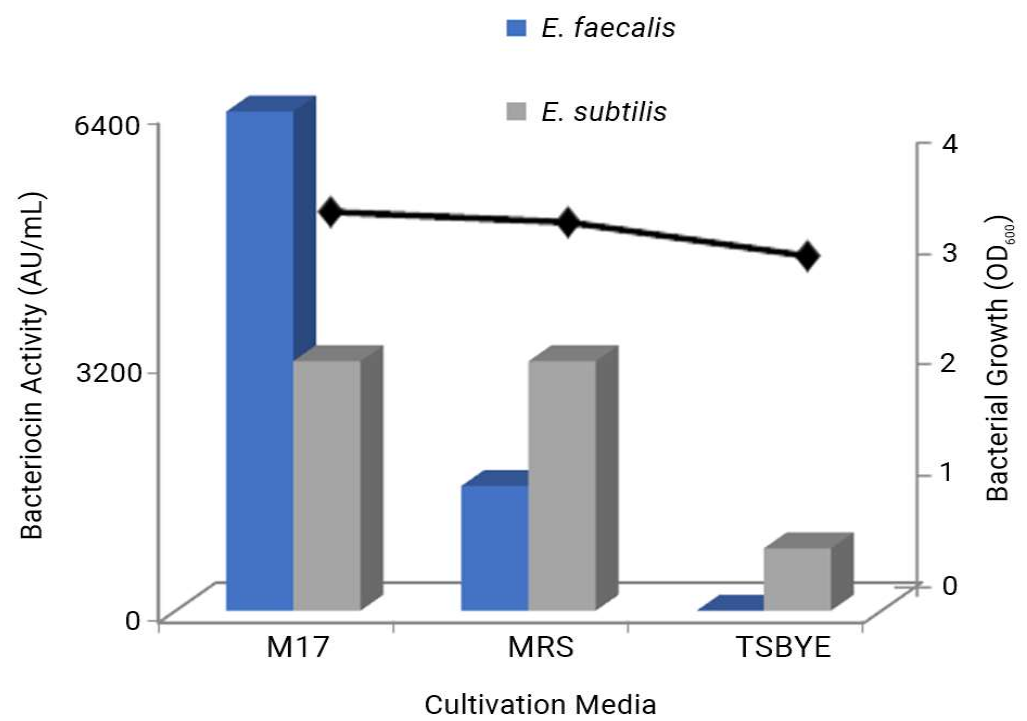

Figure 1. Bacteriocin production of Enterococcus faecium NKR-5-3 as influenced by different standard cultivation media. Strain NKR-5-3 was cultivated in three cultivation media: M17, MRS, and TSBYE and subsequent bacteriocin activity of the cell-free supernatant was quantified using spot-on-lawn assay using E. faecalis JCM 5803 (sensitive to all NKR-5-3 bacteriocins) and Bacillus subtilis JCM 1465 (sensitive only to Ent53B) as indicator strains. Corresponding growth of strain NKR-5-3 after cultivation in these three media was determined by measuring the absorbance of the culture broth. Values represent the means from three independent replications. Standard deviations are not indicated as its values are very low. 


\section{Critical fermentation factors that influence the production of multiple bacteriocins}

\section{Influence of Carbon and Nitrogen Source on Bacteriocin Production}

The effect of different carbon and nitrogen sources on bacteriocin production of strain NKR-5-3 was evaluated by purposely modifying the carbon and nitrogen source components of the M17 basal cultivation medium. As expected, without a carbon source, growth and bacteriocin production were negatively affected. Fourhundred percent $(400 \%)$ and $226 \%$ reduction in the total and specific bacteriocin production were observed in the absence of a carbon source in the cultivation media. In contrast, the highest total and specific bacteriocin production were noticeable when sucrose was utilized as a sole carbon source. An 8-fold and 7.3fold increase in the total and specific bacteriocin production, respectively, were observed in sucrose-containing media compared with the standard M17 medium. Interestingly, very low bacteriocin production was observed when cellobiose was used as a carbon source despite almost comparable growth in standard M17 medium. This equates to a very low bacteriocin production per bacterial cell (specific bacteriocin production) almost as low as production without a carbon source (Table 2).

Table 2. Influence of carbon source on bacteriocin productions of E. faecium NKR-5-3

\begin{tabular}{lrrrr}
\hline & \multicolumn{4}{c}{ Parameters $^{\star *}$} \\
\cline { 2 - 5 } Carbon source & Final pH & Growth $\left(\mathrm{OD}_{600}\right)$ & $\begin{array}{r}\text { Bacteriocin } \\
\text { production }(\mathrm{AU} \\
\text { per } \mathrm{mL}) \star \star *\end{array}$ & $\begin{array}{c}\text { Specific bacteriocin } \\
\text { production } \\
\left(\mathrm{AU} / \mathrm{mL} / 0 \mathrm{D}_{600}\right)\end{array}$ \\
\hline Without carbon source & $7.17 \pm 0.00$ & $1.96 \pm 0.03$ & $400 \pm 0.00$ & $204 \pm 3.00$ \\
Standard M17 & $5.94 \pm 0.01$ & $3.46 \pm 0.02$ & $1600 \pm 0.00$ & $462 \pm 3.10$ \\
Fructose & $6.39 \pm 0.01$ & $2.80 \pm 0.02$ & $1600 \pm 0.00$ & $571 \pm 1.20$ \\
Galactose & $6.46 \pm 0.01$ & $2.60 \pm 0.02$ & $1600 \pm 0.00$ & $615 \pm 5.50$ \\
Glucose & $6.34 \pm 0.01$ & $3.20 \pm 0.01$ & $1600 \pm 0.00$ & $500 \pm 0.90$ \\
Xylose & $6.66 \pm 0.01$ & $1.46 \pm 0.02$ & $400 \pm 0.00$ & $274 \pm 3.30$ \\
Lactose & $5.86 \pm 0.00$ & $3.36 \pm 0.02$ & $3200 \pm 0.00$ & $952 \pm 4.90$ \\
Maltose & $5.54 \pm 0.01$ & $2.80 \pm 0.02$ & $800 \pm 0.00$ & $286 \pm 1.20$ \\
Sucrose & $5.86 \pm 0.01$ & $3.80 \pm 0.01$ & $12800 \pm 0.00$ & $3368 \pm 10.20$ \\
Cellubiose & $6.28 \pm 0.01$ & $3.40 \pm 0.02$ & $800 \pm 0.00$ & $235 \pm 1.20$ \\
\hline
\end{tabular}

*Carbon source in M17 medium was removed and replaced with alternative component

** values represent means from three independent replications (Mean SD)

$\star \star \star$ bioactivity unit against $L$. sakie subs. sakie JCM $1157^{\top}$ as indicator strain

The influence of a nitrogen source on bacteriocin production of the strain NKR5-3 is summarized in Table 3. Without any nitrogen source, strain NKR-5-3 showed poor growth and was unable to produce detectable amounts of bacteriocins. Among the alternative nitrogen sources, yeast extract appeared to be the most preferred for growth and bacteriocin production of this strain. Despite better growth in standard M17 medium, bacteriocin activity was 4-fold higher in the modified medium containing yeast extract as the sole nitrogen source than in standard M17 medium. This equates to a 4.27-fold higher bacteriocin production per bacterial cell. The influence of yeast extract as the sole nitrogen medium on bacteriocin production appeared to be concentration-dependent, which peaked around a $3 \%$ level. Beyond this level, slightly higher growth was observed but no further increase in bacteriocin production (Figure 2). 
Perez et al

Table 3. Influence of nitrogen source on bacteriocin production of E. faecium NKR-5-3

\begin{tabular}{|c|c|c|c|c|}
\hline \multirow[b]{2}{*}{ Nitrogen source* } & \multicolumn{4}{|c|}{ Parameters ${ }^{\star \star}$} \\
\hline & Final pH & $\begin{array}{l}\text { Growth } \\
\left(0 D_{600}\right)\end{array}$ & $\begin{array}{l}\text { Bacteriocin } \\
\text { production } \\
(\mathrm{AU} / \mathrm{mL})^{\star \star \star}\end{array}$ & $\begin{array}{c}\text { Specific bacteriocin } \\
\text { production } \\
\left(\mathrm{AU} / \mathrm{mL} / \mathrm{OD}_{600}\right)\end{array}$ \\
\hline w/o Nitrogen Source & $5.86 \pm 0.01$ & $0.14 \pm 0.04$ & $0 \pm 0.00$ & $0 \pm 0.00$ \\
\hline Standard M17 & $5.95 \pm 0.00$ & $3.50 \pm 0.08$ & $1600 \pm 0.00$ & $457 \pm 11.00$ \\
\hline Polypeptone & $5.78 \pm 0.01$ & $1.52 \pm 0.02$ & $200 \pm 0.00$ & $132 \pm 1.80$ \\
\hline Phytone & $5.86 \pm 0.01$ & $3.14 \pm 0.02$ & $1600 \pm 0.00$ & $510 \pm 2.50$ \\
\hline Bactopeptone & $5.87 \pm 0.01$ & $1.84 \pm 0.02$ & $800 \pm 0.00$ & $435 \pm 3.60$ \\
\hline Tryptone & $5.86 \pm 0.01$ & $2.50 \pm 0.03$ & $400 \pm 0.00$ & $160 \pm 1.70$ \\
\hline Beef Extract & $5.82 \pm 0.01$ & $1.72 \pm 0.01$ & $200 \pm 0.00$ & $116 \pm 0.70$ \\
\hline Yeast Extract & $5.85 \pm 0.00$ & $3.28 \pm 0.02$ & $6400 \pm 0.00$ & $1951 \pm 9.10$ \\
\hline
\end{tabular}

*nitrogen source in M17 medium was removed and replaced with alternative component

** values represent means from three independent replications (Mean SD)

*** bioactivity unit against L. sakie subs. sakie JCM $1157^{\top}$ as indicator strain

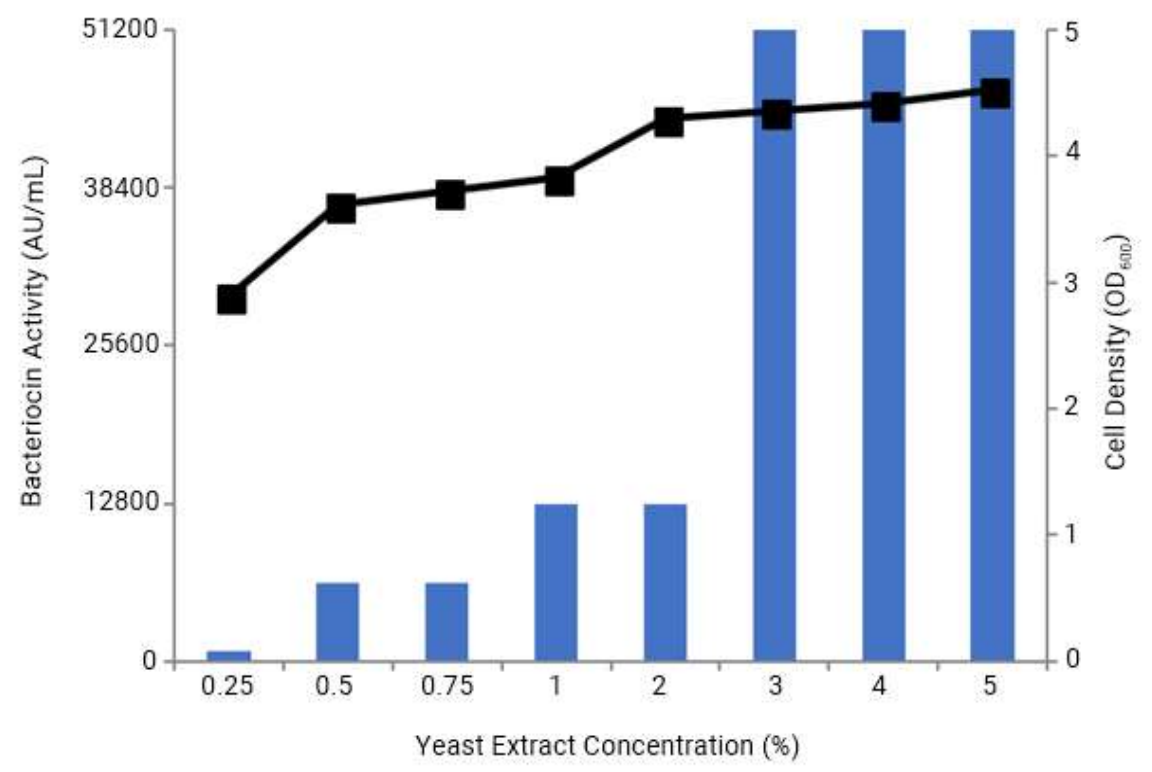

Figure 2. Bacteriocin production of Enterococcus faecium NKR-5-3 as influenced by the level of yeast extract as sole nitrogen source in M17 basal medium. Bacteriocin activity of the cell-free supernatant was quantified using the spot-on-lawn assay using Lactobacillus sakei subs. sakei JCM 1157 as indicator strain. Corresponding growth of strain NKR-5-3 after cultivation in these modified media were determined by measuring the absorbance of the culture broth. Values represent the means from three independent replications. Standard deviations are not indicated as its values are very low. 


\section{Critical fermentation factors that influence the production of multiple bacteriocinPerez et al}

To further examine the effect of the identified critical medium components on bacteriocin production of strain NKR-5-3, different levels of sucrose and yeast extract were supplemented into standard M17 and TSB (Table 4). When sucrose was supplemented in standard M17 and TSB, growth and bacteriocin production was improved. However, further improvement in bacteriocin production was no longer evident when the sucrose concentration was increased from $0.5 \%$ to $1.0 \%$. In the yeast extract supplementation, however, concentration-dependent improvement of both cell growth and bacteriocin production was observed. Increasing the yeast extract supplementation from $0.5 \%$ to $1.0 \%$ in the $\mathrm{M} 17$ medium further improved bacteriocin production by a 4-fold and 3.98-fold increase in total and specific bacteriocin production, respectively. However, the same concentration-dependent improvement of bacteriocin production by yeast extract supplementation in the TSB medium was not observed, suggesting the presence of a possible limiting factor in TSB medium. However, when both sucrose and yeast extract were supplemented together in M17 and TSB, further improvement on bacteriocin production was apparent. This was more evident in the less nutritious medium TSB. When both sucrose and yeast extract were supplemented in TSB, 8-fold and 7.9-fold improvement in total and specific bacteriocin production were observed.

Table 4. Supplementation of critical carbon and nitrogen sources

\begin{tabular}{|c|c|c|c|c|}
\hline \multirow[b]{2}{*}{ Supplemented component* } & \multicolumn{4}{|c|}{ Parameters ${ }^{\star \star}$} \\
\hline & Final pH & $\begin{array}{l}\text { Growth } \\
\left(0_{600}\right)\end{array}$ & $\begin{array}{l}\text { Bacteriocin } \\
\text { production } \\
(\mathrm{AU} / \mathrm{mL})^{\star \star}\end{array}$ & $\begin{array}{c}\text { Specific } \\
\text { bacteriocin } \\
\text { production } \\
\left(\mathrm{AU} / \mathrm{mL} / \mathrm{OD}_{600}\right)\end{array}$ \\
\hline Standard M17 & $5.79 \pm 0.00$ & $3.50 \pm 0.02$ & $1600 \pm 0.00$ & $457 \pm 2.60$ \\
\hline M17 + Sucrose (0.5\%) & $5.34 \pm 0.01$ & $3.76 \pm 0.02$ & $3200 \pm 0.00$ & $851 \pm 4.70$ \\
\hline M17 + Sucrose (1\%) & $5.25 \pm 0.01$ & $3.82 \pm 0.03$ & $3200 \pm 0.00$ & $838 \pm 5.50$ \\
\hline M17 + Yeast Extract $(0.5 \%)$ & $5.65 \pm 0.01$ & $3.88 \pm 0.02$ & $3200 \pm 0.00$ & $825 \pm 3.30$ \\
\hline M17 + Yeast Extract (1\%) & $5.54 \pm 0.01$ & $3.90 \pm 0.02$ & $12800 \pm 0.00$ & $3282 \pm 13.00$ \\
\hline $\begin{array}{c}\text { M17 + Yeast Extract }(0.5 \%)+ \\
\text { Sucrose }(0.5 \%)\end{array}$ & $5.15 \pm 0.01$ & $3.95 \pm 0.02$ & $25600 \pm 0.00$ & $6481 \pm 25.00$ \\
\hline Standard TSB & $5.51 \pm 0.00$ & $2.50 \pm 0.03$ & $0 \pm 0.00$ & $0 \pm 0.00$ \\
\hline TSB + Sucrose $(0.5 \%)$ & $5.08 \pm 0.01$ & $3.00 \pm 0.07$ & $400 \pm 0.00$ & $133 \pm 3.00$ \\
\hline TSB + Sucrose (1\%) & $4.86 \pm 0.01$ & $3.00 \pm 0.02$ & $400 \pm 0.00$ & $133 \pm 1.00$ \\
\hline TSB + Yeast Extract (0.5\%) & $5.40 \pm 0.01$ & $3.32 \pm 0.04$ & $400 \pm 0.00$ & $120 \pm 1.40$ \\
\hline TSB + Yeast Extract (1\%) & $5.36 \pm 0.01$ & $3.38 \pm 0.02$ & $400 \pm 0.00$ & $118 \pm 0.70$ \\
\hline $\begin{array}{c}\text { TSB + Yeast Extract }(0.5 \%)+ \\
\text { Sucrose }(0.5 \%)\end{array}$ & $5.02 \pm 0.01$ & $3.42 \pm 0.02$ & $3200 \pm 0.00$ & $936 \pm 4.20$ \\
\hline
\end{tabular}




\section{Influence of Incubation Temperature}

The influence of incubation temperature on the growth and bacteriocin production of strain NKR-5-3 was evaluated by incubating it at different temperatures from 20 to $40^{\circ} \mathrm{C}$. As expected, incubation temperature was a critical fermentation factor that influenced both growth and bacteriocin production (Figure 3). The highest bacteriocin production was observed at $25^{\circ} \mathrm{C}$. At this incubation temperature, strain NKR-5-3 exhibited an almost 2-fold higher bacteriocin production per cell than at $30^{\circ} \mathrm{C}$ incubation temperature. Interestingly, comparable bioactivities were observed against $B$. subtilis JCM 1465 , an indicator strain sensitive only to Ent53B, when strain NKR-5-3 was incubated at 20 to $30^{\circ} \mathrm{C}$ whereas variable antimicrobial activities were evident against $E$. faecalis JCM 5803 , which is known to be sensitive to all NKR-5-3 bacteriocins, at these incubation temperatures. Furthermore, despite better growth at $35^{\circ} \mathrm{C}$ incubation temperature than at $20^{\circ} \mathrm{C}$, strain NKR-5-3 was able to produce more bacteriocin at the lower incubation temperature. Noticeable reduction of bacteriocin activity was evident beyond $30^{\circ} \mathrm{C}$ incubation temperature. At $40^{\circ} \mathrm{C}$, strain NKR-5-3 can no longer produce detectable amounts of bacteriocins despite considerably good growth.

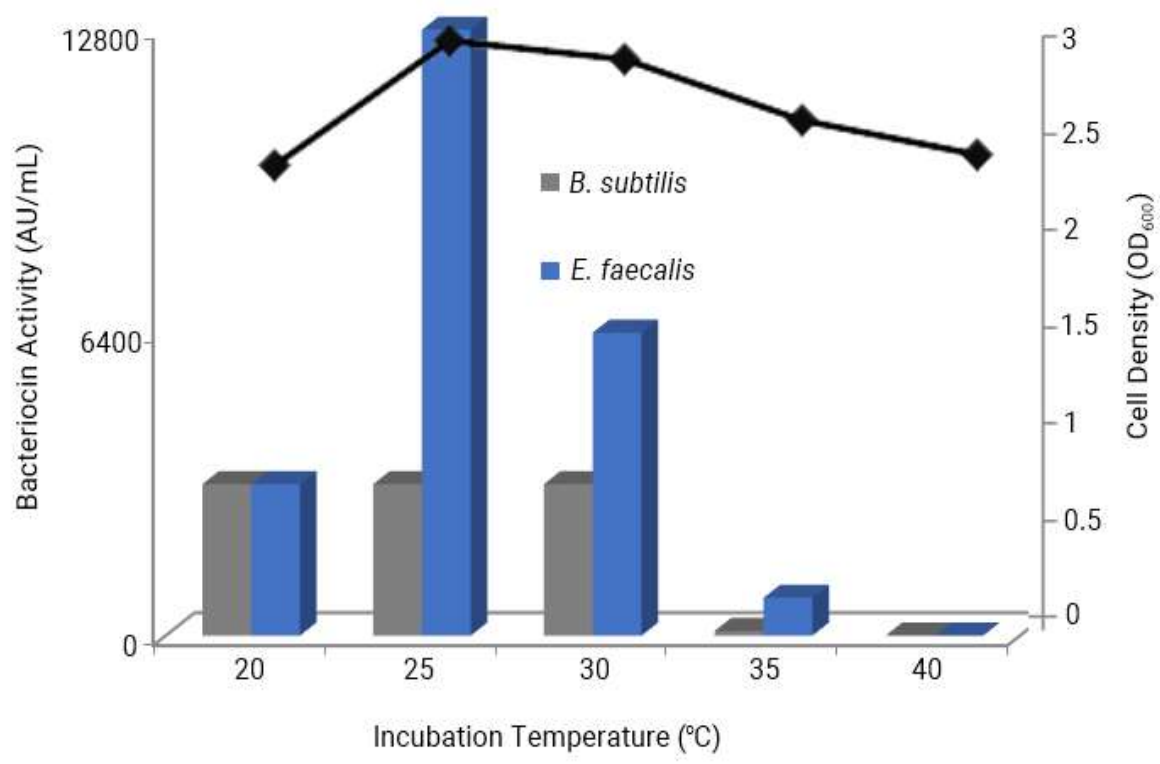

Figure 3. Bacteriocin production of Enterococcus faecium NKR-5-3 as influenced by incubation temperature. Bacteriocin activity of the cell-free supernatant was quantified using the spot-onlawn assay using E. faecalis JCM 5803 (sensitive to all NKR-5-3 bacteriocins) and Bacillus subtilis JCM 1465 (sensitive only to Ent53B) as indicator strains. Corresponding growth of the strain NKR5-3 after cultivation in different incubation temperatures were determined by measuring the absorbance of the culture broth. Values represent the means from three independent replications. Standard deviations are not indicated as its values are very low. 


\section{Critical fermentation factors that influence the production of multiple bacteriocins}

\section{DISCUSSION}

In this present study, the influence of some critical fermentation factors on the production of the bacteriocins of E. faecium NKR-5-3 were evaluated. It is a wellestablished fact that bacteriocins are primary metabolites, and hence their products are directly associated with the growth of the producing strain. Bacteriocin biosynthesis observed in many bacterial species starts during the onset of the exponential phase of growth and increases to reach the maximal level at the end of the exponential phase or the beginning of the stationary phase (Daba et al 1993, Parente et al 1994, Yang \& Ray 1994). While bacteriocin production is directly correlated with growth, high bacterial growth does not necessarily ensure better bacteriocin production, highlighting the complexity of the biosynthetic machinery of bacteriocins (Møretrø et al 2000, Leroy \& De Vuyst 2002, 2005).

In the case of strain NKR-5-3, the biosynthesis of multiple bacteriocins requires factors other than growth. The significantly higher bacteriocin activity against $E$. faecalis JCM 5803 in M17 medium relative to the MRS medium despite the comparable growth in these media suggests the presence of possible limiting factors that hindered the maximum biosynthesis of multiple bacteriocins of this strain when cultivated in MRS. However, the comparable bioactivity that the strain exhibited against $B$. subtilis JCM 1465 , which is sensitive only to Ent53B, is indicative that the production of Ent53B is independent of the production system of the rest of the NKR-5-3 bacteriocins. This observation is in agreement with the earlier reported biosynthetic gene architecture of the NKR-5-3 bacteriocins. Four of the NKR-5-3 bacteriocins, Ent53A, C, D, and Z were found to be encoded in a single biosynthetic gene cluster wherein these bacteriocins share a common extracellular transport and production regulatory mechanisms (Ishibashi et al 2014). The shared regulatory mechanism of the four NKR-5-3 bacteriocins requires more coordinated expression of the biosynthetic genes and thus requiring additional conditions other than growth. It was recently reported that a quorum-sensing-based regulatory system of production known as the three-component system is involved in the biosynthesis of these four NKR-5-3 bacteriocins (Ishibashi et al in press). The biosynthetic machinery of Ent53B is encoded in a separate operon independent from the rest of the NKR-5-3 bacteriocins (Perez et al 2016). The production of only Ent53B in TSBYE suggests that its production is more connected with the growth of strain NKR-5-3 and thus is controlled through a simpler system.

Although the molecular mechanism of the regulation of the genetic transcription of the bacteriocin biosynthetic genes under the quorum-sensing system is already well established. Fermentation conditions such as the ionic strength, $\mathrm{pH}$, cultivation media, and incubation temperature were shown to indirectly affect this regulatory mechanism by influencing the interplay of the components of the quorum-sensing system, thereby indirectly affecting the production rates of the bacteriocins. It has been demonstrated that media composition, particularly carbon and nitrogen sources, has a significant influence on the production of bacteriocins (Cheigh et al 2002, De Carvalho et al 2009). Although mineral ions are also important medium components that affect bacteriocin producer strains' growth, their influence on bacteriocin production is not as significant as that of carbon and nitrogen sources. In fact several studies have shown that some ions can reduce bacteriocin production. $\mathrm{Mg}^{2+}$ and $\mathrm{Mn}^{2+}$ ions 
were shown to reduce the production of nisin Z (Matsusaki et al 1996), while $\mathrm{Ca}^{2+}$ ions remarkably suppressed bacteriocin production of $E$. mundtii QU2 (Zendo et al 2005). Hence, in this present study, more attention was given to the identification of specific carbon and nitrogen sources that can significantly influence the production of the multiple bacteriocins of strain NKR-5-3. Bacteriocin production of this strain has a specific preference for the type of carbon and nitrogen sources, highlighting the complexity of its biosynthetic process. Carbon and nitrogen sources that can support good growth of strain NKR-5-3 do not necessarily equate to good production of its bacteriocins. For instance, cellobiose as a sole carbon source supported a considerably good growth of strain NKR-5-3, but its bacteriocin production was significantly low. One possible reason is that perhaps this particular carbon source cannot fully support the synthesis of the required concentration of enzymes responsible for bacteriocin synthesis. Apparently, sucrose and yeast extract are the most preferred carbon and nitrogen sources, respectively, for the growth and bacteriocin production of strain NKR-5-3. It has been demonstrated by other studies that the efficiency of utilization of specific sugars, such as sucrose, is dependent on the efficiency of the strain's phosphotransferase transport systems (Martin \& Russell 1987).

Meanwhile, the influence of yeast extract on bacteriocin production and general metabolic activity of many lactic acid bacteria species has already been well demonstrated by many investigators (Benthin et al 1994, De Vuyst et al 1996, Aasen et al 2000). Compared to other nitrogen-rich protein hydrolysates, yeast extract has more growth factors and has a relatively larger proportion of free amino acids and short peptides, two to three amino acids long, that are easily utilizable for the metabolic activity of the bacterial cells (Aasen et al 2000). The critical influence of yeast extract was further demonstrated by the concentration-dependent improvement of both the growth and bacteriocin production of strain NKR-5-3. The leveling-off of bacteriocin activity that was observed beyond the maximum yeast extract concentration of $3.0 \%$ could be due to the possible presence of other limiting factors such as the restrictions on the gene expression levels of the bacteriocin biosynthetic genes (Leroy \& De Vuyst 1999). The non-improvement of bacteriocin production in TSB medium with the increase of yeast extract concentration further underscores the possible presence of limiting factors of bacteriocin biosynthesis in the TSB medium. It should be noted that bacteriocin production was notably improved with the increasing concentration of yeast extract supplemented into the standard M17 medium.

On the other hand, the temperature has been demonstrated as a major factor that influences growth and bacteriocin production. In most reported studies, bacteriocin production is more pronounced at temperatures above $20^{\circ} \mathrm{C}$ and drops significantly at temperatures 35 to $40^{\circ} \mathrm{C}$ (De Vuyst et al 1996, Aasen et al 2000, Diep et al 2000). A similar result was observed in the case of the production of multiple bacteriocins of strain NKR-5-3. The highest bacteriocin production was observed at $25^{\circ} \mathrm{C}$ and significantly diminished beyond $30^{\circ} \mathrm{C}$. Bacteriocin production was totally abolished at $40^{\circ} \mathrm{C}$ incubation temperature. This observation of higher bacteriocin production at lower temperatures may be due to some temperature-dependent rate-limiting reactions, resulting in more efficient utilization of energy and increased availability of essential metabolites for bacteriocin biosynthesis (Aasen et al 2000). This makes more biological sense because even though bacteriocins 


\section{Critical fermentation factors that influence the production of multiple bacteriocins}

considered to be primary metabolites their biosynthesis is neither essential nor indispensable for the growth of the producing cells. Thus, presumably, at higher temperatures, the bacterial cell's utilization of available energy is prioritized for the general cellular metabolic activity, which is essential for its growth, rather than for bacteriocins' production.

To sum up, this paper reports the identification of critical fermentation factors, particularly specific medium components and optimum incubation temperature that favors maximum bacteriocin production of the strain NKR-5-3. The findings presented in this paper possess a huge practical implication. The significantly high cost entailed in the production of bacteriocin has been considered as the major barrier limiting the large-scale industrial utilization of these industrially important compounds. Hence, the identification of the critical fermentation factors particularly the influence of sucrose and yeast extract as carbon and nitrogen sources, respectively, as well as the understanding of the bacteriocin production behavior of strain NKR-5-3 in relation to the incubation temperature is valuable information for the future establishment of scaled-up production systems of these important compounds.

\section{ACKNOWLEDGMENTS}

The authors thank the generosity of Dr. Pongtep Wilaipun and Dr. Vichien Leelawatcharamas of Kasetsart University, Thailand, for providing the strain Enterococcus faecium NKR-5-3.

\section{REFERENCES}

Aasen IM, Møretrø T, Katla T, Axelsson L \& Storrø I. 2000. Influence of complex nutrients, temperature and $\mathrm{pH}$ on bacteriocin production by Lactobacillus sakei CCUG 42687. Applied Microbiology and Biotechnology 53:159-166

Benthin S, Schulze U, Nielsen J \& Villadsen J. 1994. Growth energetics of Lactococcus cremoris FD1 during energy-, carbon-, and nitrogen-limitation in steady-state and transient cultures. Chemical Engineering Science 49(5):589609

Cheigh Cl, Choi HJ, Park H, Kim SB, Kook MC, Kim TS, Hwang JK \& Pyun YR. 2002. Influence of growth conditions on the production of a nisin-like bacteriocin by Lactococcus lactis subsp. lactis A164 isolated from kimchi. Journal of Biotechnology 95(3):225-235

Chen $\mathrm{H}$ and Hoover DG. 2003. Bacteriocins and their food applications. Comprehensive Reviews Food Science and Food Safe 2(3):82-100

Cleveland J, Montville TJ, Nes IF \& Chikindas ML. 2001. Bacteriocins: safe, natural antimicrobials for food preservation. International Journal of Food Microbiology 71(1):1-20

Cotter PD, Hill C \& Ross RP. 2005. Bacteriocins: developing innate immunity for food. Nature reviews, Microbiology 3(10):777-788

Daba H, Lacroix C, Huang J \& Simard RE. 1993. Influence of growth conditions on production and activity of mesenterocin 5 by a strain of Leuconostoc mesenteroides. Applied Microbiology Biotechnology 39:166-173 
De Carvalho AAT, Mantovani HC, Paiva AD \& De Melo MR. 2009. The effect of carbon and nitrogen sources on bovicin $\mathrm{HC} 5$ production by Streptococcus bovis HC5. Journal of Applied Microbiology 107(1):339-347

De Vuyst L, Callewaert R \& Crabbé K. 1996. Primary metabolite kinetics of bacteriocin biosynthesis by Lactobacillus amylovorus and evidence for stimulation of bacteriocin production under unfavourable growth conditions. Microbiology 142(4):817-827

De Vuyst L and Leroy F. 2007. Bacteriocins from lactic acid bacteria: production, purification, and food applications. Journal of Molecular Microbiology and Biotechnology 13(4):194-199

Diep DB, Axelsson L, Grefsli C \& Nes IF. 2000. The synthesis of the bacteriocin sakacin $A$ is a temperature-sensitive process regulated by a pheromone peptide through a three-component regulatory system. Microbiology 146(9):2155-2160

Himeno K, Fujita K, Zendo T, Wilaipun P, Ishibashi N, Masuda Y, Yoneyama F, Leelawatcharamas V, Nakayama J, Sonomoto K. 2012. Identification of Enterocin NKR-5-3C, a novel class Ila bacteriocin produced by a multiple bacteriocin producer, Enterococcus faecium NKR-5-3. Bioscience, Biotechnology, and Biochemistry 76(6):1245-1247

Himeno K, Rosengren KJ, Inoue T, Perez RH, Colgrave ML, Lee HS, Chan LY, Henriques ST, Fujita K, Ishibashi N, Zendo T, Wilaipun P, Nakayama J, Leelawatcharamas V, Jikuya H, Craik DJ \& Sonomoto K. 2015. Identification, characterization, and the three-dimensional structure of the novel circular bacteriocin, enterocin NKR-5-3B, from Enterococcus faecium. Biochemistry 54(31):4863-4876

Ishibashi N, Himeno K, Fujita K, Masuda Y, Perez RH, Zendo T, Wilaipun P, Leelawatcharamas V, Nakayama J \& Sonomoto K. 2012. Purification and characterization of multiple bacteriocins and an inducing peptide produced by Enterococcus faecium NKR-5-3 from Thai fermented fish. Bioscience, Biotechnology, and Biochemistry 76(5):947-953

Ishibashi N, Himeno K, Masuda Y, Perez RH, Iwatani S, Zendo T, Wilaipun P, Leelawatcharamas V, Nakayama J \& Sonomoto K. 2014. Gene cluster responsible for secretion of and immunity to multiple bacteriocins, the NKR-5-3 enterocins. Applied and Environmental Microbiology 80(21):6647-6655

Ishibashi N, Matsumoto N, Perez RH, Iwatani S, Sugino H, Zendo T, Wilaipun $\mathrm{P}$, Leelawatcharamas V, Nakayama J \& Sonomoto K. Molecular characterization of the regulation of multiple bacteriocin production in Enterococcus faecium NKR-5-3. Journal of Bioscience and Bioengineering. In Press

Leroy $F$ and De Vuyst L. 1999. The presence of salt and a curing agent reduces bacteriocin production by Lactobacillus sakei CTC 494, a potential starter culture for sausage fermentation. Applied and Environmental Microbiology 65(12):5350-5356

Leroy F and De Vuyst L. 2002. Bacteriocin production by Enterococcus faecium RZS $\mathrm{C} 5$ is cell density limited and occurs in the very early growth phase. International Journal of Food Microbiology 72(1-2):155-164

Leroy $F$ and De Vuyst L. 2005. Simulation of the effect of sausage ingredients and technology on the functionality of the bacteriocin-producing Lactobacillus sakei CTC 494 strain. International Journal of Food Microbiology 100(1-3):141-152 


\section{Critical fermentation factors that influence the production of multiple bacteriocins}

Martin SA and Russell JB. 1987. Transport and phosphorylation of disaccharides by the ruminal bacterium Streptococcus bovis. Applied and Environmental Microbiology 53(10):2388-2393

Matsusaki H, Endo N, Sonomoto K \& Ishizaki A. 1996. Lantibiotic nisin Z fermentative production by Lactococcus lactis 10-1: relationship between production of the lantibiotic and lactate and cell growth. Applied Microbiology and Biotechnology 45(1-2):36-40

Møretrø T, Aasen IM, Storrø I \& Axelsson L. 2000. Production of sakacin P by Lactobacillus sakei in a completely defined medium. Journal of Applied Microbiology 88(3):536-545

Parente E, Ricciardi A \& Addario G. 1994. Influence of pH on growth and bacteriocin production by Lactococcus lactis subsp. lactis 140NWC during batch fermentation. Applied Microbiology and Biotechnology 41(4):388-394

Perez RH, Ishibashi N, Inoue T, Himeno K, Masuda Y, Sawa N, Zendo T, Wilaipun P, Leelawatcharamas V, Nakayama J \& Sonomoto K. 2016. Functional analysis of the genes involved in the biosynthesis of enterocin NKR-5-3B, a novel circular bacteriocin. Journal of Bacteriology 198(2):291-300

Perez RH, Zendo T \& Sonomoto K. 2014. Novel bacteriocins from lactic acid bacteria (LAB): various structrures and applications. Microbial Cell Factories 13(Supplement 1):S3

Yang R and Ray B. 1994. Factors influencing production of bacteriocins by lactic acid bacteria. Food Microbiology 11(4):281-291

Zendo T, Eungruttanagorn N, Fujioka S, Tashiro Y, Nomura K, Sera Y, Kobayashi G, Nakayama J, Ishizaki A \& Sonomoto K. 2005. Identification and production of a bacteriocin from Enterococcus mundtii QU 2 isolated from soybean. Journal of Applied Microbiology 99(5):1181-1190 